\title{
Effect of Modification of Ovary Preservation Solution by Adding Glucose on the Maturation and Development of Pig Oocytes after Prolonged Storage
}

\author{
Asami SAKAMOTO ${ }^{1)}$, Hisataka IWATA ${ }^{1)}$, Hirosumi SATO ${ }^{1)}$, \\ Takeshi HAYASHI ${ }^{1)}$, Takehito KUWAYAMA ${ }^{1)}$ and Yasunori MONJI') \\ 1)Tokyo University of Agriculture, Department of Animal Science, Funako 1737, Atsugi, \\ Kanagawa 246-0034, Japan
}

\begin{abstract}
Oocytes lose their developmental competence during prolonged storage of the ovary. In the present study, we supplemented the preservation solution for pig ovaries (phosphate buffered saline, PBS) with glucose and preserved the ovaries for $6 \mathrm{~h}$ at $25 \mathrm{C}$. Subsequently, we examined the glucose concentration of the follicular fluid $(\mathrm{FF}), \mathrm{pH}$ of the FF, survival rate of the granulosa cells, and maturation and developmental competence of oocytes after storage. During storage, the glucose concentration of the FF $(2.1 \mathrm{mM})$, pH of the FF (7.4), and survival rate of the granulosa cells $(69.5 \%)$ rapidly decreased (glucose concentration: under $1.1 \mathrm{mM} ; \mathrm{pH}: 6.8$; and survival rate: $43 \%$ ). On the other hand, when the preservation solution was supplemented with glucose $(15 \mathrm{mM})$, the glucose concentration of the FF increased and the survival rate of the granulosa cells improved, although the $\mathrm{pH}$ of the FF decreased further (from 6.8 to 6.6). In addition, supplementation with glucose significantly improved the rates of oocytes at metaphase II ( $0 \mathrm{~h}: 65.0 \%$; $6 \mathrm{~h}$ without glucose: $23.8 \%$; and $6 \mathrm{~h}$ with glucose: $43.8 \%$ ) and attenuated the decline in the rates of fertilization and development that resulted from prolonged storage, although there were no significant differences. In conclusion, modification of the preservation solution by the addition of glucose increased the glucose concentration of the FF and improved the rate of maturation of pig oocytes.
\end{abstract}

Key words: Ovary preservation, Glucose, Pig oocyte

(J. Reprod. Dev. 52: 669-674, 2006)

$\mathbf{0}$ ocyte quality is a major factor that affects the developmental rate of in vitro matured/in vitro fertilized oocytes to the blastocyst stage. For in vitro embryo production in domestic animals, oocytes are generally aspirated from ovaries collected at a slaughterhouse. These ovaries are preserved in physiological saline or phosphate buffered saline (PBS) at 30-35 C for a predetermined time period before oocyte collection. During ovary preservation, the supply of oxygen and blood flow to the ovaries is halted; thus, the oocytes are

Accepted for publication: June 22, 2006

Published online: July 28, 2006

Correspondence: H. Iwata (e-mail: h1iwata@nodai.ac.jp) maintained under ischemic conditions. During bovine ovary preservation, a decrease in both the glucose concentration of the folliclular fluid (FF) and the survival rate of the granulosa cells in the follicle and an increase in the potassium ion $\left(\mathrm{K}^{+}\right)$ concentration of the FF indicate that the oocyte and surrounding cells are exposed to suboptimal conditions compared with the in vivo conditions [1, 2]. In general, to prevent ischemic injuries, a delicate balance of the energy levels within the ovary during storage is thought to be achieved by two strategies, (1) reducing the activity of energyconsuming processes, and (2) increasing the rate of energy production (via glycolysis). Lowering the 
temperature of the preservation solution has been used for mammalian ovaries; this method improved the quality of the oocytes obtained from ovaries preserved for a long period of time [2-8], although preservation of porcine ovaries at $15 \mathrm{C}$ reduced the quality of the oocytes compared with that at $25 \mathrm{C}$. On the other hand, it has been reported that the glucose level in the tissue and exhaustion of anaerobic glycolysis are essential factors that determine the tolerance limit under ischemic conditions [9]. However, few reports have studied the effect of supplementing ovary preservation solution with an energy substrate on the developmental competence of oocytes collected from ovaries preserved for a long period of times. In the present study, the solution used for preserving pig ovaries was supplemented with 0,5 or $15 \mathrm{mM}$ glucose, and the $\mathrm{pH}$ and glucose concentration of the FF of these ovaries, survival rate of the granulosa cells, and maturation and developmental competences of the oocytes collected from the ovaries were assessed after prolonged storage.

\section{Materials and Methods}

Ovary preservation, survival rate of the granulosa cells and glucose concentration in the FFs

Pig ovaries were collected from a local slaughterhouse and transported to the laboratory within $0.5 \mathrm{~h}$ of collection at $37 \mathrm{C}$. Immediately after ovary arrival at the laboratory, they were randomly divided into three preservation solutions containing 0,5 or $15 \mathrm{mM}$ of glucose maintained at $25 \mathrm{C}$. The preservation solutions for the ovaries were based on PBS without $\mathrm{Mg}^{++}$and $\mathrm{Ca}^{++}$. After storing the ovaries for 0 or $6 \mathrm{~h}$, the granulosa cells, FFs, and cumulus-oocyte complexes (COCs) were aspirated from the small antral follicles (3-6 $\mathrm{mm}$ in diameter) of 10 ovaries in each preservation solution with a $10 \mathrm{ml}$-syringe connected to an 18gauge needle. After collecting the COCs, each sample was centrifuged ( $500 \mathrm{~g} \times 5 \mathrm{~min}$ ) in order to collect the remaining granulosa cells, and the supernatant $(\mathrm{FF})$ was centrifuged further $(5 \mathrm{~min} \times$ $7,000 \mathrm{~g}, 4 \mathrm{C}$ ). The collected granulosa cells were tested for their survival rate by staining with 3\% trypan blue. A total of 200 granulosa cells were observed in each trial $(\times 4)$, and the number of living cells (unstained) and dead cells (stained) were counted. The FF samples were then transferred into a test tube and stored at $-35 \mathrm{C}$ until examination. Glucose concentrations were measured using a Spotchem-SE electrolyte analyzer (Arkray Inc., Kyoto, Japan) as described previously [1], and the $\mathrm{pH}$ of the FFs were analyzed using a $\mathrm{pH}$ meter.

\section{In vitro maturation, fertilization and culture}

COCs were collected from ovaries in preservation solution supplemented with 0 or 15 $\mathrm{mM}$ of glucose. Oocyte maturation and fertilization were performed as described previously [10]. Briefly, COCs were cultured in maturation medium (modified North Carolina State University 37) [11] containing $10 \%(\mathrm{v} / \mathrm{v})$ porcine $\mathrm{FF}, 0.6 \mathrm{mM}$ cysteine, $1 \mathrm{mM}$ dibutyryl cAMP (dbcAMP; Sigma, St. Louis, MO, USA), and hormones $[(10 \mathrm{IU} / \mathrm{ml}$ equine chrionic gonadtropin (eCG) and $10 \mathrm{IU} / \mathrm{ml}$ human chrionic gonadotropin (hCG)] for the first $20 \mathrm{~h}$ of the maturation period (44 $h$ ) and were then transferred to maturation medium without dbcAMP and hormones for $24 \mathrm{~h}$. After $44 \mathrm{~h}$ of culture, all oocytes were separated from the cumulus cells, that enclosed the oocytes by gently pipetting with $0.2 \%$ hyaluronidase (Sigma). In order to examine nuclear maturation, the oocytes were fixed with acetic acid/ethanol (1:3, v/v) for 24 $h$, stained with aceto orcein, and evaluated by checking for the metaphase II (M II) stage chromosome under a phasecontrast microscope $(x$ 400). Only those oocytes with intact cytoplasm and a first polar body were used for fertilization. The fertilization medium was based on pig fertilization medium (Pig-FM) and was modified according to a previous report [12]. Oocytes were fertilized with thawed semen that had been collected from a single boar (Chester White) and were frozen in lactoseegg yolk-glycerol-Orvus ES Paste (Nova Chemical Sales, Scituate, MA, USA) extender at a final concentration of $1 \times 10^{7}$ cells $/ \mathrm{ml}$. To assess the rate of fertilization, the oocytes were fixed $10 \mathrm{~h}$ after fertilization and stained with orcein. Only oocytes that contained a male and female pronuclei with an intact nuclear membrane were considered to be normal fertilized oocytes. Maturation and fertilization was carried out at $39 \mathrm{C}$ under $5 \% \mathrm{CO}_{2}$ in air with maximum humidity. Five hours after insemination, the oocytes were transferred to culture medium and cultured for 7 days; the rate of blastulation was then examined. PZM4 culture 
Table 1. Effect of glucose supplementation of ovary preservation solution on the glucose concentration of the FF and $\mathrm{pH}$ of the FF collected from pig ovaries preserved for 1 and $6 \mathrm{~h}$

\begin{tabular}{cccccc}
\hline \multirow{2}{*}{$\begin{array}{c}\text { Glucose } \\
\text { concentration } \\
(\mathrm{mM})\end{array}$} & \multicolumn{2}{c}{ Glucose concentration $(\mathrm{mM})$ in the FF $\pm \mathrm{SE}$} & \multicolumn{2}{c}{$\mathrm{pH}$ of the FF $\pm \mathrm{SE}$} \\
\cline { 2 - 6 } & $0^{*}$ & 1 & 6 & $0^{*}$ & 6 \\
\hline 0 & $2.1 \pm 0.1$ & Under $^{* *}$ & Under $^{* *}$ & $7.4 \pm 0.0$ & $6.8 \pm 0.1^{\mathrm{a}}$ \\
5 & $2.1 \pm 0.1$ & $2.2 \pm 0.1$ & $1.1 \pm 0.0$ & $7.4 \pm 0.0$ & $6.6 \pm 0.1^{\mathrm{b}}$ \\
15 & $2.1 \pm 0.1$ & $3.9 \pm 0.1$ & $3.4 \pm 0.5$ & $7.4 \pm 0.0$ & $6.6 \pm 0.1^{\mathrm{b}}$ \\
\hline
\end{tabular}

${ }^{*} 0$ : FF was collected immediately after ovary arrival at the laboratory.

**The glucose concentration was a value of less than $1.1 \mathrm{mM}$.

${ }^{\mathrm{a}-\mathrm{b}}$ Different superscripts within the same column denote significant differences $(\mathrm{P}<0.05)$.

Table 2. The survival rate of pig granulosa cells collected from ovaries stored for $6 \mathrm{~h}$ in preservation solution supplemented with glucose

\begin{tabular}{ccccc}
\hline $\begin{array}{c}\text { Glucose } \\
\text { concentration }(\mathrm{mM})\end{array}$ & $\begin{array}{c}\text { Period } \\
(\mathrm{h})\end{array}$ & $\begin{array}{c}\text { No. of } \\
\text { tials }\end{array}$ & $\begin{array}{c}\text { No. of } \\
\text { cells }\end{array}$ & $\begin{array}{c}\text { Survival rate of } \\
\text { the cells }(\%) \pm \text { SE }\end{array}$ \\
\hline 0 & 0 & 4 & 800 & $69.5 \pm 0.7^{\mathrm{a}}$ \\
0 & 6 & 4 & 800 & $43.0 \pm 3.6^{\mathrm{b}}$ \\
15 & 6 & 4 & 800 & $51.2 \pm 4.3^{\mathrm{ab}}$ \\
\hline
\end{tabular}

*0: Granulosa cells were collected immediately after ovary arrival at the laboratory. 6: Granulosa cells were collected after preservation of ovaries $(6 \mathrm{~h})$.

${ }^{\mathrm{a}-\mathrm{b}}$ Different superscripts within the same column denote significant differences $(\mathrm{P}<0.05)$.

medium was used as described by Yoshioka et al. [13].

\section{Statistical analysis}

To analyze the $\mathrm{pH}$ and glucose concentration of the FFs, rates of nuclear maturation, fertilization, and development to the blastocyst stage, and survival rate of the granulosa cells, we compared the frequencies of data using the Fisher's protected least significant difference (PLSD) test followed by analysis of variance (ANOVA). Developmental data was subjected to an arcsine transformation before statistical analysis. $\mathrm{P}<0.05$ was considered to be significant.

\section{Results}

Immediately after arrival of the ovaries at the laboratory $(0.5 \mathrm{~h}$ after collection), the glucose concentration of the FF was $2.1 \mathrm{mM}$; it rapidly decreased to a value of less than $1.1 \mathrm{mM}$ within $1 \mathrm{~h}$ (Table 1). In addition, supplementation of the preservation solution with $5 \mathrm{mM}$ glucose maintained the glucose concentration within $1 \mathrm{~h}$
(2.2 $\mathrm{mM})$, but it decreased to $1.1 \mathrm{mM}$ after $6 \mathrm{~h}$ of preservation. However, addition of $15 \mathrm{mM}$ glucose to the preservation solution increased the glucose concentration to $3.9 \mathrm{mM}$. The $\mathrm{pH}$ of the FF collected from the ovaries just after their arrival at the laboratory was 7.4 (Table 1). However, during ovary preservation $(6 \mathrm{~h})$, the $\mathrm{pH}$ decreased to 6.8 , and addition of glucose to the preservation solution further decreased the $\mathrm{pH}$ to 6.6. The survival rate of the granulosa cells collected from the ovaries just after their arrival at the laboratory was $69.5 \%$, and during preservation, it decreased to $43.0 \%$ (Table 2). However, addition of glucose to the preservation solution increased the survival rate to $51.2 \%$. Preservation of ovaries for $6 \mathrm{~h}$ significantly decreased the rate of maturation, and this rate was significantly improved when the preservation solution was supplemented with glucose (Table 3). In addition, ovary preservation increased the rate of polyspermic fertilization from 17.7 to $32.1 \%$, and it was improved to $20.7 \%$ when the preservation solution was supplemented with glucose (Table 4). When oocytes were collected from ovaries without preservation, the rate of development to the blastocyst stage was $10.0 \%$. When the ovaries were 
Table 3. Effect of glucose supplementation of ovary preservation solution on the maturation of pig oocytes

\begin{tabular}{ccccc}
\hline $\begin{array}{c}\text { Glucose } \\
\text { concentration }(\mathrm{mM})\end{array}$ & $\begin{array}{c}\text { Period* } \\
(\mathrm{h})\end{array}$ & $\begin{array}{c}\text { No. of } \\
\text { trials }\end{array}$ & $\begin{array}{c}\text { No. of } \\
\text { oocytes }\end{array}$ & $\begin{array}{c}\text { Rate of oocytes } \\
\text { at MII }(\%) \pm \text { SE }\end{array}$ \\
\hline 0 & 0 & 4 & 80 & $65.0 \pm 2.0^{\mathrm{a}}$ \\
0 & 6 & 4 & 80 & $23.8 \pm 2.4^{\mathrm{b}}$ \\
15 & 6 & 4 & 80 & $43.8 \pm 3.1^{\mathrm{c}}$ \\
\hline
\end{tabular}

${ }^{*} 0$ : COCs were collected immediately after ovary arrival at the laboratory. 6: COCs were collected after preservation of ovaries $(6 \mathrm{~h})$.

${ }^{\mathrm{a}-\mathrm{b}}$ Different superscripts within the same column denote significant differences $(\mathrm{P}<0.05)$.

Table 4. Effect of glucose supplementation of ovary preservation solution on the development of pig oocytes after in vitro maturation and fertilization

\begin{tabular}{ccccccc}
\hline $\begin{array}{c}\text { Glucose } \\
\text { concentration }(\mathrm{mM})\end{array}$ & Hours $^{*}$ & $\begin{array}{c}\text { No. of } \\
\text { trials }\end{array}$ & $\begin{array}{c}\text { No. of } \\
\text { oocytes }\end{array}$ & & Fertilization (\%) \pm SE & Development to \\
\cline { 5 - 6 } & & 4 & 80 & $32.8 \pm 4.1$ & $17.7 \pm 1.3^{\mathrm{a}}$ & $10.0 \pm 1.1^{\mathrm{a}}$ \\
0 & 0 & 4 & 80 & $22.7 \pm 2.5$ & $32.1 \pm 2.6^{\mathrm{b}}$ & $3.8 \pm 1.4^{\mathrm{b}}$ \\
0 & 6 & 4 & 80 & $37.6 \pm 4.9$ & $20.7 \pm 6.5^{\mathrm{ab}}$ & $7.5 \pm 2.0^{\mathrm{ab}}$ \\
\hline
\end{tabular}

*0: COCs were collected immediately after ovary arrival at the laboratory. 6 : COCs were collected after preservation of ovaries $(6 \mathrm{~h})$.

${ }^{a-b}$ Different superscripts within the same column denote significant differences $(\mathrm{P}<0.05)$.

preserved for $6 \mathrm{~h}$, the developmental rate was significantly reduced $(3.8 \%)$. However, this reduction was attenuated by glucose supplementation in the preservation solution $(7.5 \%)$, although there was no significant difference.

\section{Discussion}

During ovary preservation, the occlusion of blood flow reduces the oxygen and energy supply and creates ischemic conditions. In ischemic ovaries, the physiological states of the COCs and the FF surrounding the COCs are thought to change dramatically. There have been reports indicating that potassium ion $\left(\mathrm{K}^{+}\right)$efflux from cells maintained under ischemic conditions is a predictor of cell apoptosis [14-20] and that the concentration of $\mathrm{K}^{+}$of the FF collected from bovine ovaries preserved for a long period of time also significantly increases during preservation [2]. In addition, in the present study, the survival rate of the granulosa cells significantly decreased, from 69.5 to $43.0 \%$, during ovary preservation; when bovine ovaries were preserved for a long period of times $(9 \mathrm{~h})$, a reduction in the survival rate of the granulosa cells was also observed [2]. These reports and the present study show that the granulosa cells and oocytes are exposed to suboptimal conditions and are injured by ischemic conditions. Generally, one of the key factors in organ preservation is restoration of the ATP concentration in the tissues during preservation [9, 21]. It has been shown that maintaining the preservation solution at a low temperature is beneficial for restoring the developmental competence of oocytes obtained from ovaries preserved for a long period of time [2-8]. Supplementation with an energy substrate is another method of restoring organ activity. In the present study, the glucose concentration of the FF decreased to a value of less than $1.1 \mathrm{mM}$ within $1 \mathrm{~h}$ of storage. In addition, when bovine ovaries were preserved for $3 \mathrm{~h}$ at $30 \mathrm{C}$, the glucose concentration of the $\mathrm{FF}$ also showed a decrease from 3.5 to $1.9 \mathrm{mM}$ [1]. This report and the results of the present study demonstrate that the COCs are maintained under hypoglycemic conditions. In the present study, the ovaries were collected about $0.5 \mathrm{~h}$ after the animals were slaughtered, and were then transported to the laboratory within $0.5 \mathrm{~h}$. Considering the rapid decline of the glucose concentration of the FF during preservation, the glucose concentration of 
FF in vivo is speculated to be over $4 \mathrm{mM}$, although direct measurement of the glucose concentration of FF is required. In the present study, when the preservation solution was supplemented with glucose (5 or $15 \mathrm{mM}$ ), the glucose concentration of the FF increased in a dose-dependent manner (5 $\mathrm{mM}$ glucose: $2.2 \mathrm{mM}$; $15 \mathrm{mM}$ glucose: $3.9 \mathrm{mM}$ ). In addition, Hopkinson et al. [22] have examined the effects of saccharides as osmotic impermeants on lung preservation and have suggested that of the many mono and disaccharides, glucose has the highest membrane permeability. From these reports and the results of the present study, movement of glucose from the preservation solution into the FF may partly depend on passive diffusion. In the present study, the mechanism by which glucose added to the preservation solution was metabolized was not elucidated. However, our previous study has shown that there is a significant negative correlation between the concentrations of glucose and lactic acid in the FF [23]. Furthermore, the $\mathrm{pH}$ of the FF rapidly decreased during preservation of the pig ovaries (7.4 to 6.8) and addition of glucose further decreased the $\mathrm{pH}$ of the FFs (6.6). Based on this report and the present study, we believe that when preservation solution is supplemented with glucose, the glucose is transferred into the follicles and is used as an energy substrate by the granulosa cells and oocytes, thereby preventing these cells from sustaining ischemic injury. Glucose conversion to lactic acids may be one of the cause of acidification of the FF.

In conclusion, preservation of pig ovaries for a long period of time reduced the glucose concentration of the $\mathrm{FF}, \mathrm{pH}$ of the $\mathrm{FF}$, survival rate of the granulosa cells, rate of maturation and blastulation of the oocytes, and increased polyspermic fertilization. Modification of the ovary preservation solution by glucose supplementation increased the glucose concentration in the FF and significantly increased the rate of maturation of the oocytes obtained from ovaries preserved for a prolonged period.

\section{References}

1. Iwata $\mathbf{H}$, Hashimoto $\mathbf{S}$, Ohota $\mathbf{M}$, Kimura $\mathbf{K}$, Shibano S, Miyake M. Effects of follicle size and electrolytes and glucose in maturation medium on nuclear maturation and developmental competence of bovine oocytes. Reproduction 2004; 127: 159-164.

2. Iwata H, Hayashi T, Sato H, Kimura K, Kuwayama T, Monji Y. Modification of ovary stock solution with magnesium and raffinose improved the developmental competence of oocytes after long preservation. Zygote 2005; 13: 303-308.

3. Blondin P, Coenen K, Guilbault LA, Sirard MA. In vitro production of bovine embryos: Developmental competence is acquired before maturation. Theriogenology 1997; 47: 1061-1075.

4. Mitchell SJ, Churchill TA, Winslet MC, Fuller BJ. Effects of different cold preservation solutions on restoration of hepatic energy metabolism during cold reperfusion. Cryobiology 1996; 33: 413-422.

5. Schernthaner W, Schmoll F, Brem G Schellander K. Storing bovine ovaries for 24 hours between 15 and $21 \mathrm{C}$ dose not influence in vitro production of blastocyst. Theriogenology 1997; 47: 297(abst).

6. Ferreira MAL, Brasil AF, Silva JRV, Andrade ER, Rodrigues APR, Figueiredo JR. Effects of storage time and temperature on atresia of goat ovarian preantral follicles held in M199 with or without indole-3-acetic acid supplementation. Theriogenology 2001; 55: 1607-1617.
7. Lucci CM, Kacinskis MA, Rumpf R, Báo SN. Effects of lowered temperatures and media on short-term preservation of zebu (Bos indicus) preantral ovarian follicles. Theriogenology 2004; 61: 461-472.

8. Wongsrikeao P, Otoi T, Karja NW, Agung B, Nii M, Nagai T. Effects of ovary storage time and temperature on DNA fragmentation and development of porcine oocytes. Reprod Dev 2005; 51: 87-97.

9. Hayreh SS, Weingeist TA. Experimental occlusion of the central artery of the retina. IV: Retinal tolerance time to acute ischemia. $\mathrm{Br} J$ Ophthalmol 1980; 64: 818-825.

10. Hayashi T, Sato $\mathbf{H}$, Iwata $\mathbf{H}$, Kuwayama $\mathbf{T}$, Monji Y. Inhibitory effect of Ca-ionophore pretreatment of porcine oocytes on polyspermic fertilization. Zygote 2006; 14: 17-22.

11. Petters RM, Wells KD. Culture of pig embryos. $J$ Reprod Fertil 1993; 48: 61-73.

12. Suzuki K, Eriksson B, Shimizu H, Nagai T, Rodriguez-Martinez $\mathbf{H}$. Effect of hyaluronan on monospermic penetration of porcine oocytes fertilized in vitro. Int J Androl 2000; 23: 13-21.

13. Yoshioka K, Suzuki C, Tanaka A, Anas IM, Iwamura S. Birth of piglets derived from porcine zygotes cultured in a chemically defined medium. Biol Reprod 2002; 66: 112-119. 
14. Lareau S, Boyle AJ, Stewart LC, Deslauriers R, Hendry P, Keon WJ, Labow RS. The role of magnesium in myocardial preservation. Magnes Res 1995; 8: 85-97.

15. Bortner CD, Hughes FM Jr, Cidlowski JA. A primary role for $\mathrm{K}^{+}$and $\mathrm{Na}^{+}$efflux in the activation of apoptosis. Biol Chem 1997; 272: 32436-32442.

16. Hughes FM Jr, Bortner CD, Purdy GD, Cidlowski JA. Intracellular $\mathrm{K}+$ suppresses the activation of apoptosis in lymphocytes. J Biol Chem 1997; 272: 30567-30576.

17. McCarthy JV, Cotter TG. Cell shrinkage and apoptosis: a role for potassium and sodium efflux. Cell Death Differ 1997; 4: 756-770.

18. Bortner CD, Cidlowski JA. Caspases independent/ dependent regulation of $\mathrm{K}+$, cell shrinkage, and mitochondria membrane potential during lymphocyte apoptosis. J Biol Chem 1999; 274: 2195321962.

19. Vu CC, Bortner CD, Cidlowski JA. Differential involvement of initiator caspases in apoptotic volume decrease and potassium efflux during Fasand UV-induced cell death. J Biol Chem 2001; 276: 37602-37611.

20. Xiao AY, Wei L, Xia S, Rothman S, Yu SP. Ionic mechanism of ouabain-induced concurrent apoptosis and necrosis in individual cultured cortical neurons. J Neurosci 2002; 22: 1350-1362.

21. Minor T, Klauke H, Vollmar B, Isselhard W, Menger MD. Biophysical aspects of liver aeration by vascular persufflation with gaseous oxygen. Transplantation 1997; 63: 1843-1846.

22. Hopkinson DN, Odom NJ, Bridgewater BJ, Hooper TI. Comparison of saccharides as osmotic impermeants during hypothermic lung graft preservation. Transplantation 1996; 27: 1667-1671.

23. Iwata $H$, Inoue J, Kimura $K$, Kuge $T$, Kuwayama $T$, Monji Y. Comparison between the characteristics of follicular fluid and the developmental competence of bovine oocytes. Ani Reprod Sci 2006; 91: 215-223. 